\title{
STUDY OF EFFECTIVE OMNI-DIRECTIONAL VERTICAL AXIS WIND TURBINE FOR LOW SPEED REGIONS
}

\author{
Alisher BekMurdovich SAfarov ${ }^{1}$ And Rasul Akif-Ogli Mamedov ${ }^{2}$ * \\ ${ }^{1}$ Department of Energy Audit, \\ ${ }^{2}$ Department of Energy, \\ Bukhara Engineering Technological Institute, Bukhara, Uzbekistan. \\ *Corresponding author: rasul_91-92@mail.ru
}

(Received: $4^{\text {th }}$ August 2020; Accepted: $16^{\text {th }}$ January 2021; Published on-line: $4^{\text {th }}$ July 2021)

\begin{abstract}
This article presents theoretical and experimental studies of an improved vertical axis wind power device that generates electricity in areas with an average wind speed of 3.5-4.5 m/s. An algorithm has been developed for determining the geometrically optimal dimensions of the outer guiding surfaces to improve the efficiency of the device at low wind speeds. The device uses an AFPMG generator with opposite rotation of the stator and rotor. Matlab/Simulink and Solidworks were used to develop a mathematical and physical model of the wind power device. According to the results of the study, it was found that the developed wind power device can reach a rated power of $700 \mathrm{~W}$ at a wind speed of $8 \mathrm{~m} / \mathrm{s}$. The use of the device in areas with low wind speed is based on the possibility of increasing the efficiency of work by $5-10 \%$ at an average wind speed lower than that of other types of wind power devices.
\end{abstract}

ABSTRAK: Artikel ini memaparkan kajian teori dan eksperimen berkenaan alat kuasa angin paksi menegak yang diperbaharui dan menghasilkan tenaga elektrik di kawasan kelajuan angin berpurata 3.5-4.5 m/s. Algoritma telah dibangunkan bagi menentukan dimensi optimum geometri permukaan berpandu luar dalam meningkatkan kecekapan peranti pada kelajuan angin yang kurang. Peranti ini menggunakan penjana AFPMG dengan putaran stator dan rotor yang berlawanan. Matlab/Simulink dan Solidworks digunakan bagi menghasilkan model matematik dan fizikal peranti tenaga angin. Berdasarkan dapatan kajian, didapati bahawa alat tenaga angin yang dibangunkan ini dapat mencapai daya kuasa sebanyak $700 \mathrm{~W}$ pada kecepatan angin $8 \mathrm{~m} / \mathrm{s}$. Penggunaan alat ini di kawasan kurang kelajuan angin berkemungkinan meningkatkan efisiensi purata kerja sebanyak $5-10 \%$ pada kelajuan angin rendah, iaitu lebih rendah daripada segala jenis peranti tenaga angin lain.

KEYWORDS: wind energy; low speed generator; external reference surface; vertical axis wind turbine; AFPMG generator

\section{INTRODUCTION}

The increase in greenhouse gas emissions into the atmosphere, due to the burning of natural fuel sources, leads to such negative consequences as climate change. This, in turn, makes it important to increase the share of humankind that uses clean energy sources. The use of renewable energy sources such as sun, wind, biomass, geothermal energy, and hydropower is rapidly developing [1-5]. Due to the low cost of electricity generated from renewable energy sources, and the fact that it is practically harmless to the environment, such projects are increasingly being implemented, large investments are made in them, and promising developments and research are supported. 
Currently, among renewable energy sources, the use of wind energy is one of the most promising projects. Today, more than 100 countries use wind energy to provide people and industries with a reliable and clean energy source. China, India, and Brazil are leading the way in the design and implementation of vertical-axis wind farms. By 2024, the world plans to increase the use of vertical wind power plants by $24 \%$ [6].

$65-70 \%$ of the territory of the Republic of Uzbekistan is steppes and deserts, and 4$5 \%$ of the population lives in remote areas. Continuity and reliability of power supply remains the main problem in these areas. To meet the energy needs of the region, the possibility of using renewable energy sources is currently being evaluated. In our region there are opportunities for using solar energy, but in the desert areas, the efficiency of using solar energy is lower. The main reason for this is the high temperature and dustiness of the region.

When assessing the possibility of using the potential of wind energy, it was found that the average wind speed in this area is $3.5-4.5 \mathrm{~m} / \mathrm{s}$ at a height of $10 \mathrm{~m}[7,8,9]$. We can develop social and economic sectors by providing reliable and uninterrupted power supply to autonomous electricity consumers in remote areas of the region. By developing a new design of a wind turbine that works effectively with variable and weak wind flows, it is possible to provide autonomous consumers with reliable and uninterrupted electricity, thereby developing social and economic sectors in the region.

\section{LITERATURE REVIEW}

Solomin V. [10] in his candidate's dissertation on "Methodological foundations for the development and creation of vertical-axial wind turbines for the agro-industrial complex of Russia" in 2013 studied a new type of vertical axis wind turbine and performance methodology on the full or partial supply of electricity to small settlements, residential buildings, farms, and small workshops in order to develop infrastructure in remote areas with unstable power supply. Xiongfei P. [11] in a patent he received in 2011 for a two-rotor wind turbine, proposed a vertical-axis wind turbine with an opposite rotating top and bottom wind wheel to make efficient use of low-flow wind speeds.

Zha G. et al. [12] in their patent on a "Vertical axis wind power plant" created a wind power plant with single-rotor outer guide surfaces and inner rotating blades to supply power to urban and remote area power consumers. Pezaris D. [13] in his patent (invention) for a vertical axis wind turbine with external guide surfaces in 2011 achieved high efficiency in obtaining energy at low speed wind currents by applying a new design of external guide surfaces and internal rotating wind wheels in a vertical axis wind turbine. Yadav K. [14] in his research paper "Model and experimental test of a generator applied to a Savonius type wind turbine" simulated in Matlab/Simulink environment a mathematical model of a generator (permanent magnet synchronous generator, (PMSG)) applied to a Savonius type wind turbine. A wind power unit with a capacity of $1 \mathrm{~kW}$ was combined with a PMSG generator to study the dynamic performance of the wind turbine system.

Kaliyev V. [15] in his dissertation on "Machine without a core with permanent magnet of the current" in 2015 theoretically and practically studied a small-speed electric generator consisting of vertical axis of coreless permanent magnets. The feasibility of using this generator for low-power wind turbines has been evaluated. Efficiency has been achieved by improving the optimal size of the generator. Taran N. [16] in his research analyzed the possibilities of using axial generators of various designs consisting of permanent magnets with low rotational speeds for wind power and small micro-hydro-electric power station 
equipment operating in low-speed wind currents. In his doctoral dissertation written in 2019, the scientist presented and evaluated the methods of mathematical modeling of three types of axial generators. Ansys Fluent and Matlab/Simulink were used to analyze the optimal dimensions and energy performance of these generators for efficient operation. Lim C. et al. [17] conducted research on the possibility of applying the vertical axis of external reference surfaces to wind turbines to increase the efficiency of wind power equipment. In this study, optimal performance indicators for the use of external guide surfaces were obtained and analyzed.

Based on the analysis of the above studies, an optimal design of a wind turbine with a vertical axis, using an AFPMG generator, the stator, and rotor which rotate in opposite directions, operating under variable and weak wind flows is developed.

\section{METHODOLOGY}

\subsection{Mathematical Model of a Wind Power Plant}

For the theoretical substantiation of the operation of a wind power plant with a vertical axis, operating in variable and weak wind flows, we will construct mathematical models for the structure and the processes occurring in it.

The rate of rotation of wind turbine blades depends on the wind speed, the radius of the wind turbine wheel, and the steering angle. This ratio is determined by the following expression [18]:

$$
\lambda=\frac{\omega_{\mathrm{T}} \mathrm{R}}{\mathrm{V}}=\frac{2 \pi \mathrm{n}_{\mathrm{T}} \mathrm{R}}{60 \mathrm{~V}}
$$

where: $\omega_{\mathrm{T}}$ - is the rotation speed of the wind turbine wheel, $\mathrm{R}$ - is the radius of the wind wheel, $\mathrm{V}$ - is the wind speed, $\mathrm{n}_{\mathrm{T}}$ - is the rotational speed of the turbine rotor.

The torque coefficient of a wind turbine is determined by the following expression [19]:

$$
\mathrm{C}_{\mathrm{T}}=\frac{\mathrm{C}_{\mathrm{p}}}{\lambda}
$$

The total mechanical moment created in the blades of a wind power device is determined by the following expression [20]:

$$
\mathrm{M}_{\mathrm{T}}=\sum \mathrm{F}_{\mathrm{d}} \mathrm{R}
$$

where: $F_{d}$ - is the drag force created by the wind blades; $R$ - is the drag force created by the wind blades.

The expression for determining the drag force created by the wind blades in a stationary position is as follows [21]:

$$
\mathrm{F}_{\mathrm{d}}=\frac{1}{2} \mathrm{C}_{\mathrm{d}} \rho \mathrm{S}(\mathrm{V} \cos (\alpha))^{2}
$$

where: $\rho$ - air density; $\mathrm{S}$ - frontal area of the blade; $\mathrm{V}$ - wind speed; $\alpha$ - the angle between the wind speed direction and the normal direction of the blade surface; $C_{d}-$ drag coefficient.

When the wind power device rotates about the central axis, the blades are in two positions. They consist of front and back shapes. The drag coefficient value depends on the shape of the blades. Forward torque is generated by the forward blade shape facing the wind direction, while the opposite torque is generated by the rear blade shape facing the wind direction. 
The expression for determining the total mechanical moment created by the vanes in a stationary position is as follows [22]:

$$
\mathrm{M}_{\mathrm{CT}}=\frac{1}{2} \rho \mathrm{SR}\left[\sum_{1}^{\mathrm{i}=\mathrm{m}} \mathrm{C}_{\mathrm{d} 1}\left(\mathrm{~V} \cos \left(\alpha_{\mathrm{i}}\right)\right)^{2}-\sum_{1}^{\mathrm{i}=\mathrm{n}} \mathrm{C}_{\mathrm{d} 2}\left(\mathrm{~V} \cos \left(\alpha_{\mathrm{j}}\right)\right)^{2}\right]
$$

where: $\mathrm{C}_{\mathrm{d} 1}$ and $\mathrm{C}_{\mathrm{d} 2}$ are the drag coefficients of the front and back surfaces of the blades. $\mathrm{m}$ and $\mathrm{n}$ - the number of blades facing forward and backward in relation to the direction of the wind. R.D. Blevins gave in his scientific work the drag coefficients of the blades of wind turbines with a vertical axis. It follows from the study that the drag coefficients of the front and rear surfaces are equal to $\mathrm{C}_{\mathrm{d} 1}=2,3$ and $\mathrm{C}_{\mathrm{d} 2}=1,1[23]$.

The total mechanical moment created on the blades when they rotate with a certain angular velocity $\omega_{\mathrm{T}}$ relative to the central axis is determined as follows [24]:

$$
\mathrm{M}_{\mathrm{T}}=\frac{1}{2} \rho \mathrm{SR}\left[\sum_{1}^{\mathrm{i}=\mathrm{m}} \mathrm{C}_{\mathrm{d} 1}\left(\mathrm{~V} \cos \left(\alpha_{\mathrm{i}}\right)-\omega_{\mathrm{T}} \mathrm{R}\right)^{2}-\sum_{1}^{\mathrm{i}=\mathrm{n}} \mathrm{C}_{\mathrm{d} 2}\left(\mathrm{~V} \cos \left(\alpha_{\mathrm{j}}\right)+\omega_{\mathrm{T}} \mathrm{R}\right)^{2}\right]
$$

When using external guide surfaces in a wind turbine, the total mechanical torque generated by the blades is determined as follows:

$$
\mathrm{M}_{\mathrm{T}}=\frac{1}{2} \rho \mathrm{SR}\left[\sum_{1}^{\mathrm{i}=\mathrm{m}} \mathrm{C}_{\mathrm{d} 1}\left(\operatorname{vcos}\left(\alpha_{\mathrm{i}}\right)-\omega \mathrm{R}\right)^{2}\right]
$$

The mechanical force generated in a vertical axis wind turbine is determined by the following relationship:

$$
\mathrm{P}_{\mathrm{T}}=\mathrm{M}_{\mathrm{T}} \omega_{\mathrm{T}}=\frac{1}{2} \rho \mathrm{SR} \omega_{\mathrm{T}}\left[\sum_{1}^{\mathrm{i}=\mathrm{m}} \mathrm{C}_{\mathrm{d} 1}\left(\mathrm{~V} \cos \left(\alpha_{\mathrm{i}}\right)-\omega_{\mathrm{T}} \mathrm{R}\right)^{2}\right]
$$

To describe the rotational motion of a wind power device, we use the following differential equation [25]:

$$
\mathrm{J} \frac{\mathrm{d} \omega_{\mathrm{T}}}{\mathrm{dt}}=\mathrm{M}_{\mathrm{T}}-\mathrm{M}_{\mathrm{g}}-\mathrm{k} \omega_{\mathrm{T}}
$$

Here: $M_{T}$ - is the mechanical torque on the shaft of the wind turbine, $M_{g}$ is the electromagnetic moment of the generator, $\mathrm{k}$ is the friction coefficient, $\mathrm{J}$ is the total moment of inertia of the wind turbine, $\omega_{\mathrm{T}}$ is the rotation speed of the wind wheel.

If the blades of the windmill are turned in two directions, the total mechanical speed will be equal to their sum:

$$
\omega_{T}=\omega_{1}+\omega_{2}
$$

The total moment of inertia of the rotating parts of the device is equal to the sum of the moments of inertia of the wind turbine rotor and the generator. This relationship is defined by the following expression:

$$
\mathrm{J}=\mathrm{J}_{\mathrm{p}}+\mathrm{J}_{\Gamma}
$$

Here: $\mathrm{J}_{\mathrm{p}}$ - is the moment of inertia of the wind turbine rotor, $\mathrm{J}_{g}$ is the moment of inertia of the generator. [26]:

The moment of inertia of a wind turbine rotor is determined by the following expression

$$
\mathrm{J}_{\mathrm{p}}=\mathrm{n} \cdot \mathrm{J}_{0}=\mathrm{n} \cdot \frac{\mathrm{m}_{1} \cdot \frac{\mathrm{m}_{2}}{2}}{\mathrm{~m}_{1}+\frac{\mathrm{m}_{2}}{2}} \mathrm{l}^{2}
$$


Here: $\mathrm{n}$ - is the number of wind turbine blades, $\mathrm{m}_{1}$ - is the mass of the turbine blades, $\mathrm{m}_{2}$ is the mass of the profile connecting the turbine blades and the rotor shaft, 1 - is the distance between the centers of the turbine blades and the rotor shaft.

\subsection{Mathematical Model of External Guiding Surfaces}

As a result of the use of external guiding surfaces, the wind speed is evenly distributed in the inner rotating part, that is, on the blades of the wind power plant, thereby ensuring the stable operation of the structure. The variable movement of the wind flow is explained on the basis of the law of continuity.

The expression for the dependence of the speed of the wind flow entering and leaving the channel of the outer guide surface on the dimensions of the surface channels is as follows: [27]:

$$
\frac{V_{1}}{V_{2}}=\frac{W_{2} \cdot H_{2}}{W_{1} \cdot H_{1}}=\frac{\left[\frac{D_{2}-D_{1}}{2 \operatorname{tg} \theta}+m\right] \cdot H_{2}}{\left[\frac{D_{2}-D_{1}}{2 \operatorname{tg} \beta}+m\right] \cdot H_{1}}=\left(\frac{k+\operatorname{tg} \theta}{k+\operatorname{tg} \beta}\right) \cdot\left(\frac{\operatorname{tg} \beta}{\operatorname{tg} \theta}\right) \cdot\left(\frac{H_{2}}{H_{1}}\right)
$$

Here: $D_{1}, D_{2}$ - outer and inner diameters of the channel of the guiding surfaces, to which the wind flow is directed; $\theta, \beta$ - angles between the guiding surfaces, to which the wind flow is directed; $\mathrm{m}$ is the minimum distance between the guides to which the wind flow is directed; $\mathrm{k}$ - is the construction factor; $\mathrm{L}$ - is the distance between the outer and inner peripheral part of the guides, to which the wind flow is directed.
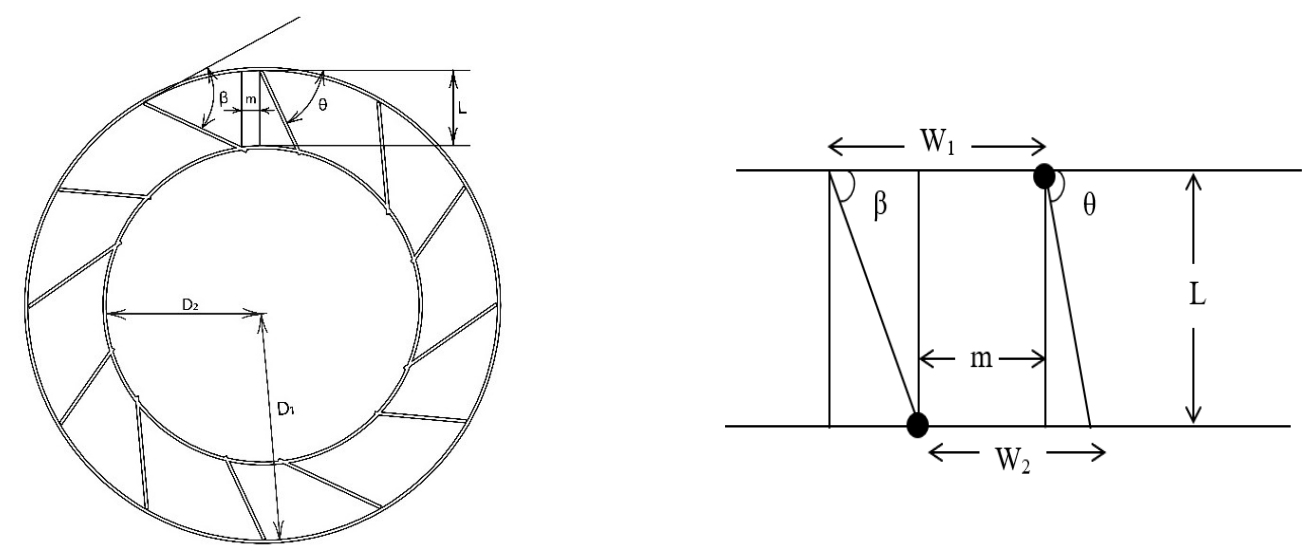

Fig. 1: Designation of the geometric dimensions of the outer guiding surfaces.

Figure 1 shows the determination of the geometric dimensions of the outer guiding surfaces $(a, b)$. Having determined the optimal values of the angles $\beta$ and $\theta$, it is possible to increase the wind speed, thereby reducing the force that adversely affects the rotating blades of the wind power plant.

Figure 2 shows an algorithm developed to determine the optimal parameters of the outer guiding surfaces, which ensures the stable operation of the device due to the uniform transmission of the wind flow through the channels to the inner part of the wind turbine, that is, on its blades.

\subsection{Mathematical Model of the Counter Rotating Generator}

To eliminate the disadvantages associated with the use of gearboxes, low-speed generators are used in many low-power wind turbines. The use of low-speed generators in wind power plants intended for use in areas with low wind speeds increases the efficiency and reliability of the devices [28]. 


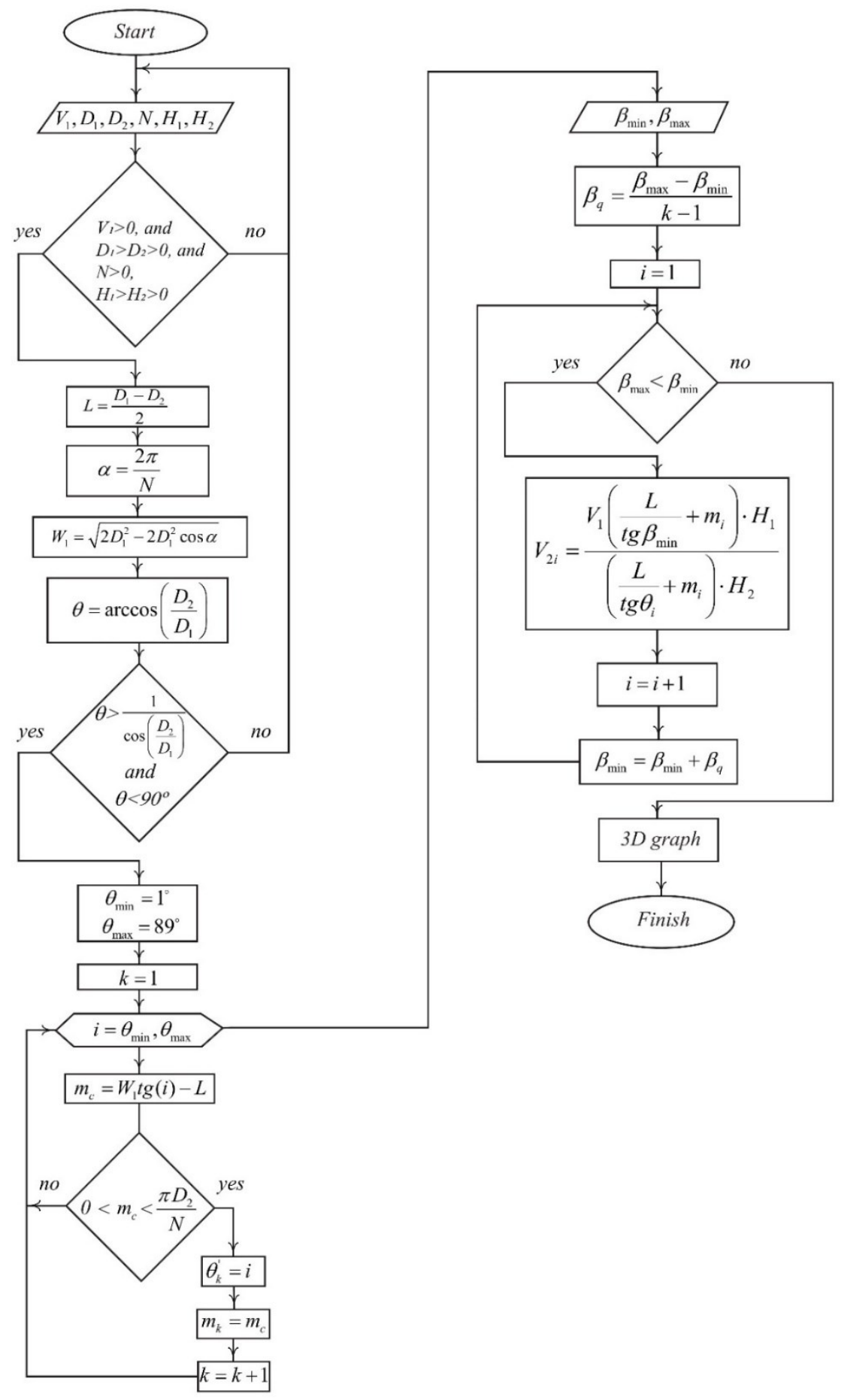

Fig. 2: Algorithm for determining the optimal parameters of external guiding surfaces.

In the developed wind power plant, a stator and rotor generator were used that rotate in opposite directions (AFPMG). For a synchronous machine with noticeable poles without a rotor winding, the voltage equations for the stator circuit [29]:

$$
\begin{aligned}
& U_{d}=R_{s} i_{d}+L_{d} \frac{d i_{d}}{d t}-\omega_{e} L_{q} i_{q} \\
& U_{q}=R_{s} i_{q}+L_{q} \frac{d i_{q}}{d t}+\omega_{e} L_{d} i_{d}+\omega_{e} \psi_{P M}
\end{aligned}
$$


The electromagnetic power of a three-phase generator consisting of permanent magnets is determined by the following expression [30]:

$$
P_{e}=\frac{3}{2} \omega_{e}\left[\psi_{P M}+\left(L_{d}-L_{q}\right) i_{d}\right] i_{q}
$$

The electromagnetic moment of the generator with the number of pole pairs $p$ is determined by the following expression [31]:

$$
T_{e}=\frac{3}{2} p\left[\psi_{P M}+\left(L_{d}-L_{q}\right) i_{d}\right] i_{q}
$$

where: $\psi_{p m}$ is the maximum flow per phase coupling for the excitation system

$$
\psi_{P M}=\frac{\sqrt{2} E_{f}}{\omega}
$$

By applying this low speed generator to a wind turbine, its efficiency can be greatly improved.

\section{RESULTS AND DISCUSSION}

Figure 3 shows the appearance of an efficient wind turbine. This wind power plant can be used by electricity consumers located far from the power supply system.
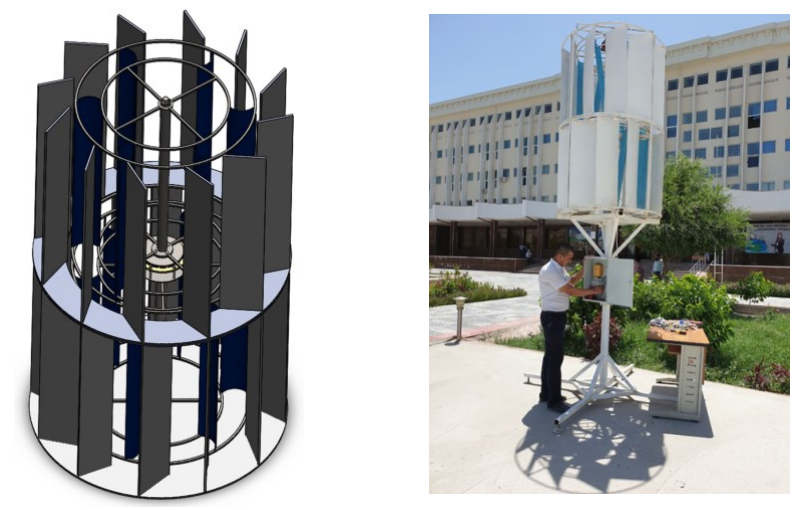

Fig. 3: External view of the wind power plant.

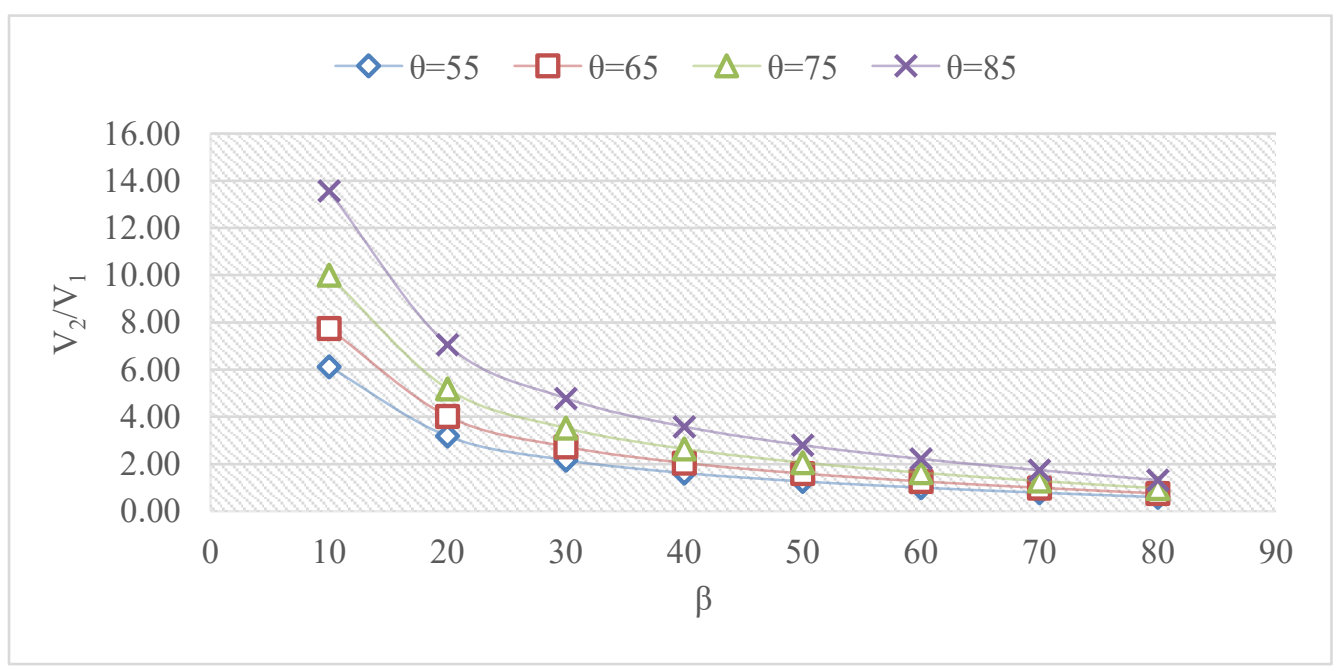

Fig. 4: Graph of the dependence of the angles of the channel surfaces $\theta$ and $\beta$ coefficient of variability of speed $\left(\mathrm{V}_{2} / \mathrm{V}_{1}\right)$ from the coefficient of construction $\mathrm{k}$. 
Figure 4 shows a graph of the dependence of the angles of the channel surfaces $\theta$ and $\beta$ of the velocity variability coefficient $\left(V_{2} / V_{1}\right)$ on the design coefficient $k$. Several values of the angles are taken and analyzed in this graph. In this case, the value of the velocity coefficient will be large for small values of the angle $\beta$ and large values of the angle $\theta$.

Figure 5 shows the results of the generated physical model of the wind power device in the Solidworks application. Accordingly, according to Bernoulli's law, when a wind flow of $4 \mathrm{~m} / \mathrm{s}$ is applied to the outer guides, it can be seen that the wind flow speed increases by 30 $50 \%$.
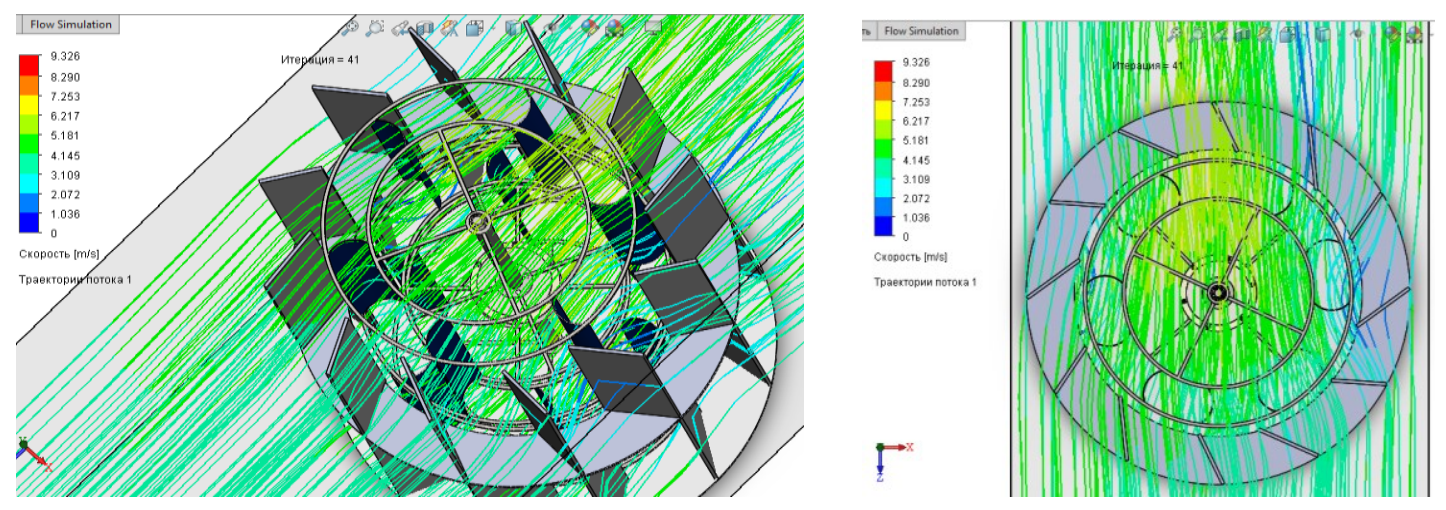

Fig. 5: A physical model of the wind power plant in the Solidworks application.

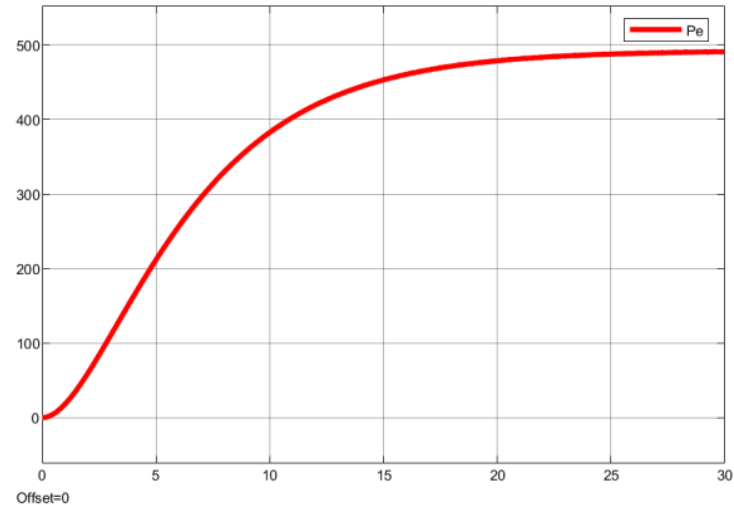

Fig. 6: Dynamic (in time) results of the electromagnetic force of a wind power plant, obtained in the Matlab/Simulink program, for a state in which the stator is stationary and the rotor rotates (W).

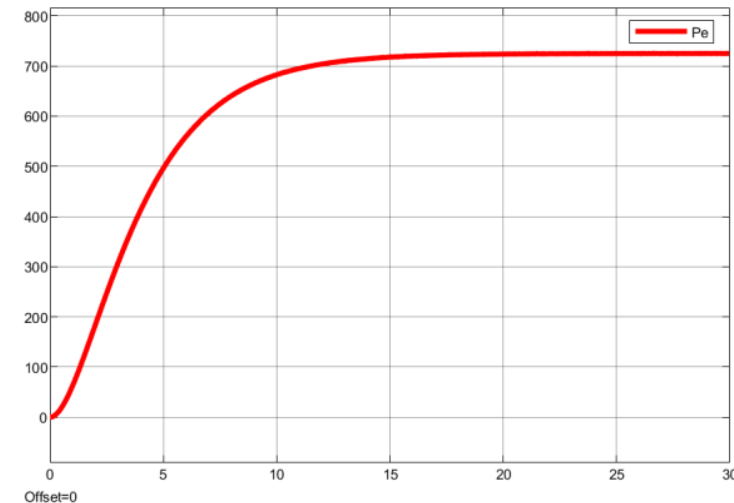

Fig. 7: Dynamic (in time) results of the electromagnetic force of a wind power plant, obtained in the Matlab/Simulink program, for a state in which the stator and rotors rotate in opposite directions $(\mathrm{W})$.

Figures 6 and 7 show graphs of the electromagnetic power (W) determined from the dynamic (in time) expression 15, built in the Matlab/Simulink program of the wind turbine. When plotting the graphs, the nominal wind speed was assumed to be $8 \mathrm{~m} / \mathrm{s}$.

Figure 8 shows the stator voltage (a) and stator current (b) at the generator output of a wind turbine rotating at rated speed. The winding of a three-phase generator is starconnected. To ensure the stable operation of the wind power plant, a low-speed generator was developed, the stator and rotors of which rotate in opposite directions (see Fig. 9). 


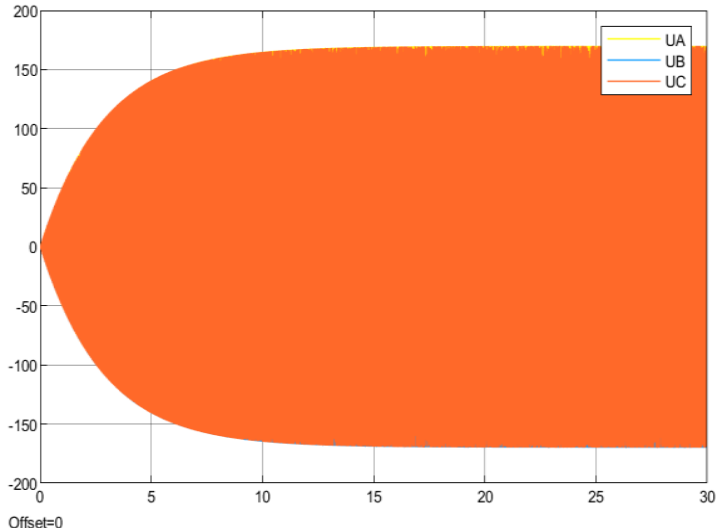

(a)

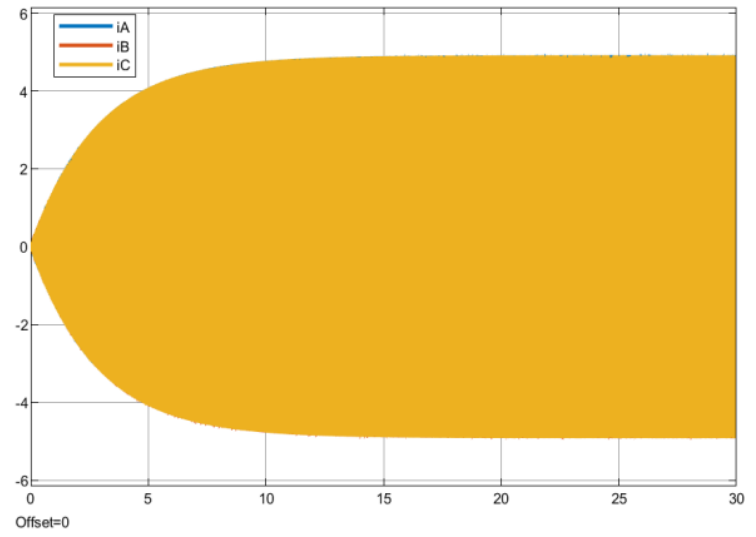

(b)

Fig. 8: Results obtained in the Matlab/Simulink program. (a) voltage of the stator winding, (b) current of the stator winding.

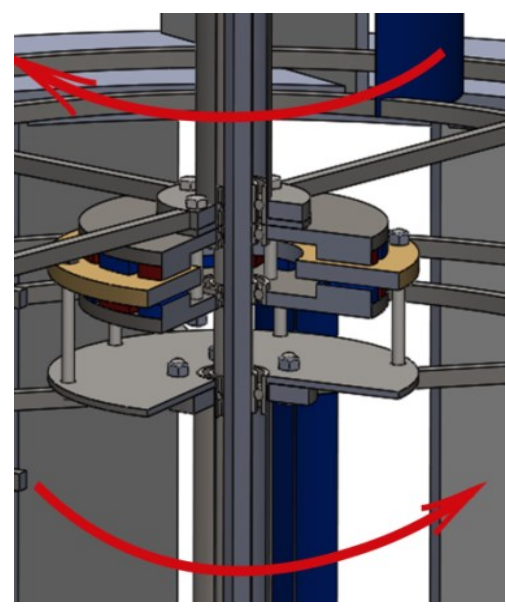

(a)

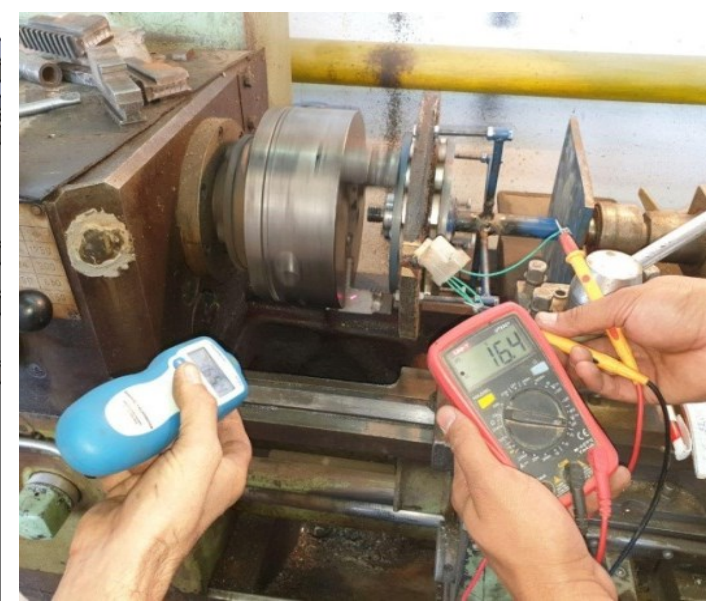

(b)

Fig. 9: External view of the developed generator in section (a), the process of experimental tests (b).

Table 1: Main parameters of an electric generator intended for a wind farm

\begin{tabular}{|c|c|c|c|}
\hline Rated power (W) & 700 & Magnetic flux, (Wb) & 0.00036 \\
\hline Stator winding inductance, $(\mathrm{H})$ & 0.000125 & Moment of inertia $(\mathrm{kg})$ & 0.18 \\
\hline Rated electromagnetic moment, (Nm) & 14 & Stator thickness (mm) & 18 \\
\hline Rated speed of rotation, (rpm) & 300 & $\begin{array}{l}\text { Air gap distance between stator and } \\
\text { magnets }(\mathrm{mm})\end{array}$ & 1.5 \\
\hline Number of pole pairs & 16 & Electromagnetic induction, $(\mathrm{T})$ & 0.6 \\
\hline $\begin{array}{l}\text { Inductive resistance of the stator } \\
\text { winding, }(\mathrm{Ohm})\end{array}$ & 0.7 & $\begin{array}{l}\text { EMF generated in the stator winding, } \\
\text { (V) }\end{array}$ & 150 \\
\hline $\begin{array}{l}\text { Active resistance of the stator } \\
\text { winding, }(\mathrm{Ohm})\end{array}$ & 12 & $\begin{array}{l}\text { Current generated in the stator winding, } \\
\text { (A) }\end{array}$ & 4.8 \\
\hline Number of windings & 12 & Number of turns in one winding & 350 \\
\hline Number of phases & 3 & Efficiency, (\%) & 90 \\
\hline
\end{tabular}


Table 1 shows the main parameters of an electric generator intended for a wind farm. These types of generators are mainly used in small wind turbines and micro hydropower plants. Figure 10 shows a comparison of the wind power device developed by us with a prototype that does not have external guide surfaces and also has a fixed stator.

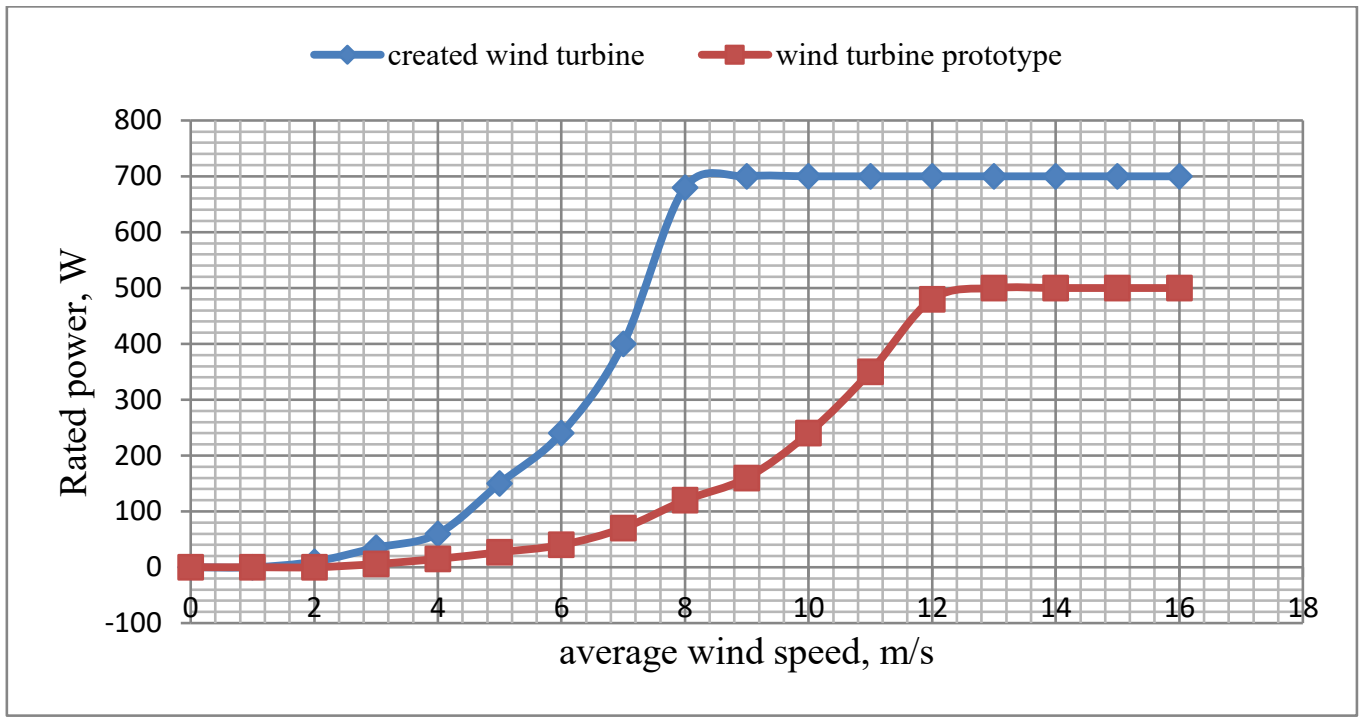

Fig. 10: Graph of the dependence of the wind speed on the rated power of the developed wind power plant from the prototype.

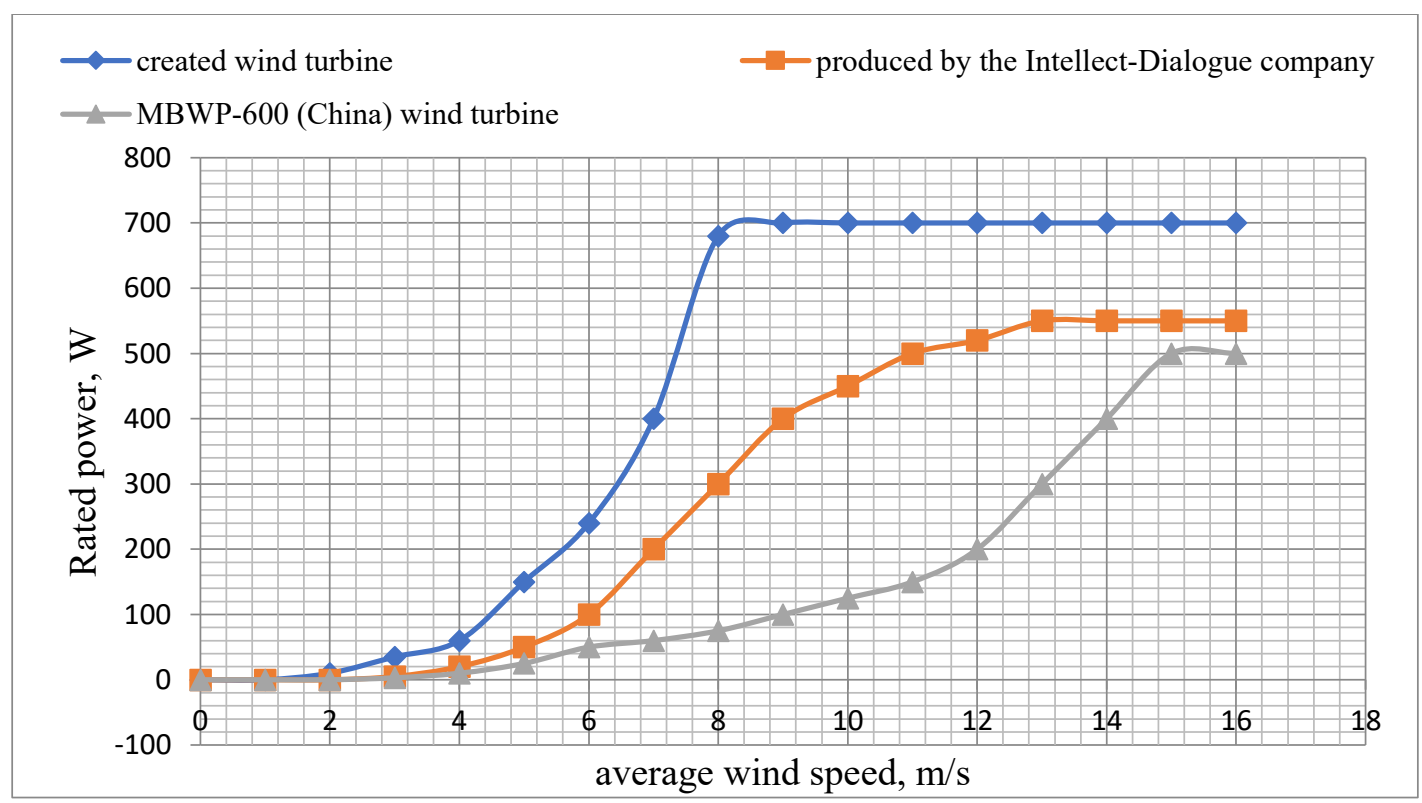

Fig. 11: Graph of the dependence of wind speed on the rated power of the developed wind power plant, as well as wind turbines produced in the Republic of Uzbekistan and a foreign prototype.

Figure 11 shows graphs comparing the wind power plant developed by us, as well as wind turbines produced in the Republic of Uzbekistan by the Intellect-Dialogue company and a prototype made in China. The research showed that the wind power device we developed works more efficiently in areas with weak wind flow in relation to prototypes with a vertical axis of rotation. 


\section{CONCLUSION}

The optimal parameters of the outer guide surfaces applied to the wind turbine are $D_{1}=$ $1.5 \mathrm{~m}, D_{2}=1 \mathrm{~m}, \mathrm{H}_{1}=\mathrm{H}_{2}, \beta=25^{0}, \theta=50^{0}$, which significantly reduces the force that negatively affects the rotation of the blades and creates the opportunity to increase the flow wind up to $30-50 \%$. Using a counter rotating AFPMG generator, it was found that the power rating of the device increased from about 500 to $700 \mathrm{~W}$ at a wind speed of $8 \mathrm{~m} / \mathrm{s}$. It was found that the developed wind power device is $5-10 \%$ higher in performance compared to low-power wind power devices with horizontal and vertical axis, currently used at low wind speeds $(3-8 \mathrm{~m} / \mathrm{s})$. Due to the use of this wind power device, it is possible to provide autonomous consumers of low-power electricity located far from the central power system, which will lead to the development of social and economic spheres.

\section{REFERENCES}

[1] Sadullaev NN, Safarov AB, Nematov ShN, Mamedov RA. (2019) Research on facilities of power supply of small power capability consumers of Bukhara region by using wind and solar energy. International Journal of Innovative Technology and Exploring Engineering, 8(9S2): 229-235.

[2] Norhafana M, Ismail AF, Majid ZAA. (2015) Performance evaluation of solar collectors using a solar simulator. IIUM Engineering Journal, 16(2): 79-90. https://doi.org/10.31436/iiumej.v16i2.606

[3] Karim MA, Amin ZM. (2015) Mathematical modelling and performance analysis of different solar air collectors. IIUM Engineering Journal, 16(2): 43-55. https://doi.org/10.31436/iiumej.v16i2.603

[4] Izanlo A, Gholamian A, Kazemi MV. (2017) Direct power control of a DFIG based wind turbins under unbalanced grid voltage without rotor position sensor. IIUM Engineering Journal, 18(1): 57-71. https://doi.org/10.31436/iiumej.v18i1.676

[5] Jami MS, Mel M, Mohd Ariff AR, Abdulazeez QM. (2018) Investigation of bioflocculant as renewable dewatering aid in sludge treatment. IIUM Engineering Journal, 19(1): 15-23. https://doi.org/10.31436/iiumej.v19i1.735

[6] Wind Turbine Market Growth Statistics [https://www.gminsights.com/industry-analysis/windturbine-market]

[7] Sadullaev NN, Safarov AB, Nematov ShN, Mamedov RA. (2019) Statistical analysis of wind energy potential in Uzbekistan's Bukhara region using Weibull distribution. Applied Solar Energy, 55(2): 126-132.

[8] Sadullayev NN, Safarov AB, Nematov ShN, Mamedov RA, Abdujabarov AB. (2020) Opportunities and prospects for the using renewable energy sources in Bukhara region. Applied Solar Energy, 56(4): 291-301.

[9] Sadullaev NN, Safarov AB, Mamedov RA, Kodirov D. (2020) Assessment of wind and hydropower potential of Bukhara region. IOP Conference Series: Earth and Environmental Science: $14-16$ October 2020

[10] Solomin EV. (2013) Methodological foundations for the development and creation of verticalaxialwind turbines for the agro-industrial complex of Russia. $\mathrm{PhD}$ thesis. South Ural State University, Electrical Engineering and Renewable Energy Department.

[11] Xiongfei P. (2011) Dual power wind turbine. China. CN102287334A.

[12] Zha G, Dano B. (2013) Vertical axis wind turbine. USA. US20130115069A1.

[13] Pezaris CD. (2011) Omnidirectional vertical-axis wind turbine. USA. US20110033288A1.

[14] Yadav YK, (2016) A Savonius wind turbine with electric generator: Model and test. PhD thesis. Clemson University, Mechanical Engineering Department.

[15] Kaliyev V. (2015) Axial Flux Permanent Magnet Coreless Machine. PhD thesis. University of Southern Queensland, Engineering Sciences Department.

[16] Taran N. (2019) Optimum Design of Axial Flux PM Machines based on Electromagnetic 3D FEA. PhD thesis. University of Kentucky, Electrical and Computer Engineering. 
[17] Lim YC, Chong WT, Hsiao FB. (2013) Performance investigation and optimization of a vertical axis wind turbine with the omni-direction-guide-vane. Procedia Engineering, 67: 5969

[18] Bezrukikh PP. (2010) Wind power. (Reference and methodological manual). Moscow, "Energia", $320 \mathrm{p}$.

[19] Lin SY, Lin YY, Bai CJ, Wang WC. (2016) Performance analysis of vertical-axis-windturbine blade with modified trailing edge through computational fluid dynamics. Renewable Energy, 99: 654-662.

[20] Ackermann T, Söder L. (2000) Wind energy technology and current status: a review. Renewable and Sustainable Energy Reviews, 4(4): 315-374.

[21] Bronstein MG. (2011) Harnessing rivers of wind: A technology and policy assessment of high altitude wind power in the U.S. Technological Forecasting and Social Change, 78: 736-746.

[22] Juangsa FB, Budiman BA, Aziz M, Soelaiman TA. (2017) Design of an airborne vertical axis wind turbine for low electrical power demands. International Journal of Energy and Environmental Engineering, 8:293-301.

[23] Blevins RD. (2003) Applied Fluid Dynamic Handbook. Florida, Krieger, 558 p

[24] Ahrens U, Diehl M, Schmehl R. (eds.) (2013) Airborne wind energy. Berlin. Springer, $611 \mathrm{p}$

[25] Obukhov SG, Sarsikeev EZh. (2012) Low power wind turbine mathematical model in Matlab Simulink. International Scientific Journal for Alternative Energy and Ecology, 2: 42-48

[26] Komass T, Sniders A. (2014) Design and verification of vertical axis wind turbine simulation model. 13th international scientific conference engineering for rural development proceedings; 29-30 May 2014; Engineering for rural development. Edited by L. Malinovska, V. Osadcuks pp. 335-340

[27] Chong WT, Fazlizana A, Poh SC, Pan KC, Hew WP, Hsiao FB. (2013) The design, simulation and testing of an urban vertical axis wind turbine with the omni-direction-guide-vane. Applied Energy, 112: 601-609.

[28] Nikbakhsh A, Izadfar H, Alinejad Beromi,Y. (2017) Design and optimization of permanent magnet synchronous generator for use in hydrodynamic renewable energy by applying ACO and FEA. IIUM Engineering Journal, 18(2): 158-176. https://doi.org/10.31436/iiumej.v18i2.705

[29] Wang W, Wang W, Mi H, Mao L, Zhang G, Liu H, Wen Y. (2018) Study and optimal design of a direct-driven stator coreless axial flux permanent magnet synchronous generator with improved dynamic performance. Energies. Suppl 11:1-22.

[30] Gieras JF, Wang R-J, Kamper MJ. (2004) Axial flux permanent magnet brushless machines. Kluwer Academic Publishers, Dordrecht

[31] Minaz MR, Çelebi M. (2017) Design and analysis of a new axial flux coreless PMSG with three rotors and double stators. Results in Physics, 7: 183-188. 